\title{
Evaluation of Soil Solarization and Flooding As Management Tools for Fusarium Wilt of Lettuce
}

\author{
Michael E. Matheron and Martin Porchas, The University of Arizona, Yuma Agricultural Center, Yuma 85364
}

\begin{abstract}
Matheron, M. E., and Porchas, M. 2010. Evaluation of soil solarization and flooding as management tools for Fusarium wilt of lettuce. Plant Dis. 94:1323-1328.

Fusarium wilt of lettuce caused by Fusarium oxysporum f. sp. lactucae continues to spread and cause economic losses in Arizona lettuce fields since the initial discovery of the disease in the state in 2001. Studies were initiated to assess the potential of summer soil solarization and flooding as management tools for Fusarium wilt of lettuce in southwestern Arizona production fields. In microplot studies, lettuce plant growth in soil naturally infested with $F$. oxysporum $\mathrm{f}$. sp. lactucae that was solarized from 2 to 8 weeks was consistently greater than growth in nonsolarized soil. Growth of lettuce in flooded soil containing the pathogen occasionally was significantly higher than in nonflooded soil; however, the effect on plant growth and health was not as consistent as that recorded for solarized soil. In four trials within a field containing $F$. oxysporum $\mathrm{f}$. sp. lactucae, the incidence of Fusarium wilt on lettuce sown in soil after solarization was reduced from 42 to $91 \%$ compared with disease in nonsolarized plots. There was no significant benefit of a 2- over a 1-month solarization period under the conditions of these trials, where the mean soil temperature at a depth of $5 \mathrm{~cm}$ during a 1-month solarization period in 2005 and 2006 was 47 and $49^{\circ} \mathrm{C}$, respectively. These findings suggest that soil solarization can be an effective tool for management of Fusarium wilt on lettuce, especially when used within an integrated program in conjunction with existing disease management tactics.
\end{abstract}

Fusarium wilt of lettuce (Lactuca sativa L.), caused by Fusarium oxysporum Schltdl.:Fr. f. sp. lactucae Matuo \& Motohashi, was first reported in Japan in 1955 (20). Since then, the disease has been reported in the United States (California and Arizona in 1990 and 2001, respectively) (9,17), Brazil (32), Iran (21), Italy (5), and Taiwan (8). Since 2001, when Fusarium wilt was first discovered in Arizona, the causal pathogen had been found in a total of 26 fields planted to lettuce by 2003 (18) and is continuing to spread and cause economic losses in infested fields.

The primary management tool for Fusarium wilt on most host plants is the use of resistant cultivars. Studies conducted in Italy identified a number of cultivars, mostly of the leaf lettuce type, that were completely resistant to $F$. oxysporum $\mathrm{f}$. $\mathrm{sp}$. lactucae after inoculation with the pathogen (6). Evaluation trials in a field naturally infested with a high population of $F$. oxysporum f. sp. lactucae in Arizona identified 2 of 16 tested romaine cultivars, Slugger and King Louie, which sustained very low levels of disease and would be considered resistant or tolerant to Fusa-

Corresponding author: M. E. Matheron

E-mail: matheron@ag.arizona.edu

Accepted for publication 6 July 2010.

doi:10.1094/PDIS-04-10-0296

(C) 2010 The American Phytopathological Society rium wilt (18). However, in the same trials, none of the 89 tested commercial crisphead cultivars were resistant to the disease. Lettuce has become the dominant vegetable crop in southwestern Arizona (Yuma County), with 24,000 ha devoted to its production in the 2007-08 growing season that runs from September through March. Crisphead (iceberg) lettuce accounts for 13,200 ha, followed by 6,700 ha of romaine and 4,000 ha of green leaf, red leaf, and butterhead types. Additional efforts are needed to identify and incorporate resistance to $F$. oxysporum f. sp. lactucae into commercially acceptable crisphead lettuce cultivars that will meet the needs of growers in the various regions where Fusarium wilt is a concern.

There are some cultural disease management strategies that can limit losses in lettuce-growing areas where $F$. oxysporum f. sp. lactucae is present. Where possible, growing lettuce at times when soil temperatures are cooler and less favorable for development of Fusarium wilt can be a very effective tactic. For example, several crisphead lettuce cultivars could be grown with losses ranging from 0 to $1.8 \%$ due to Fusarium wilt when soil temperatures were in the range of 11 to $14^{\circ} \mathrm{C}$, whereas the same set of cultivars sustained disease losses ranging from 51 to $100 \%$ in the same field when soil temperatures ranged from 21 to $32^{\circ} \mathrm{C}$ (18). Furthermore, several tested romaine cultivars which, in general, displayed more disease tolerance than crisphead cultivars, sustained losses due to
Fusarium wilt ranging from 0 to $2.3 \%$ when soil temperatures ranged from 10 to $20^{\circ} \mathrm{C}$ compared with disease losses ranging from 5.2 to $100 \%$ when soil temperatures ranged from 21 to $32^{\circ} \mathrm{C}$ (18).

Good field sanitation practices should be followed to the extent possible to minimize the spread of $F$. oxysporum f. sp. lactucae within and between fields in a lettuce production area by focusing on any farming operation that could move infested soil or plant material, such as seed-bed preparation activities, cultivation, harvesting crew operations, and movement of infested soil and plant debris on sprinklerirrigation pipe, tractors, and other farm equipment. These lettuce pathogendispersal considerations should also be kept in mind when crops other than lettuce are planted in fields infested with $F$. $o x$ ysporum f. sp. lactucae. Finally, care should be taken to sow seed not contaminated with the pathogen.

Management tools focused on lowering inoculum levels of $F$. oxysporum f. sp. lactucae in infested fields could be beneficial in reducing disease incidence as well as spread of the pathogen within and between fields. Crop rotation, which can be a useful disease management tool in this regard, is not an effective means of reducing inoculum levels of $F$. oxysporum in soil, because the pathogen may survive in the field for 10 years or more (16), even in the absence of a host (27). Soil solarization has demonstrated efficacy in reducing Fusarium wilt on several crops. Garibaldi et al. (7) reported that a simulated soil solarization at $45 \pm 2{ }^{\circ} \mathrm{C}$ for a 1 - to 2 -week period combined with soil application of dried pellets of Brassica carinata A. Braun significantly reduced Fusarium wilt on lettuce caused by $F$. oxysporum f. sp. lactucae. Chellemi et al. (3) found that the incidence of Fusarium wilt of tomato was similar in plots solarized for 40 to 55 days compared with plots fumigated with a mixture of methyl bromide + chloropicrin. Lodha (14) noted that soil solarization for 15 days led to significant reduction in the incidence of Fusarium wilt of cumin. The mechanisms of disease control brought about by solarization include physical, biological, and chemical changes in soil. The most prominent effect is the physical increase in temperature for several hours each day. Other associated processes that may also affect the survival of soilborne plant pathogens include shifts in microbial populations, changes in chemical and gas 
composition as well as the physical structure of soil, and high sustained moisture levels (10).

Flooding of soil can effectively reduce inoculum levels of some plant pathogens and reduce the incidence of the associated diseases that they cause. Moore (22) reported complete decay of sclerotia of Sclerotinia sclerotiorum (Lib.) de Bary after 24 to 45 days in three different types of flooded soils at temperatures of 22 to $26^{\circ} \mathrm{C}$. Likewise, sclerotia of S. minor Jagger and $S$. sclerotiorum were no longer viable after 3 weeks in flooded soil at mean temperatures ranging from 30 to $33^{\circ} \mathrm{C}$ (19). Furthermore, a summer flooding treatment for 60 days of soil infested with $F$. oxysporum f. sp. vasinfectum significantly reduced the occurrence of Fusarium wilt on subsequent cotton plantings (1). Soil flooding can cause physical, biological, and chemical changes, such as alterations in soil structure, anaerobic conditions (31) that modify soil microbial communities (30), decrease in nitrate nitrogen levels $(26,31)$, and an increase in ammonia concentration (26). One or more of these factors may play a role in reducing the survival of soilborne pathogen propagules. The objective of our research was to assess the potential of summer soil solarization and flooding as management tools for Fusarium wilt of lettuce in southwestern Arizona production fields.

\section{MATERIALS AND METHODS}

Microplot and bioassay trials. Soil naturally infested with $F$. oxysporum f. sp. lactucae was collected on 22 and 12 July in 2003 and 2004, respectively, from a commercial field in southwestern Arizona and placed into a series of 17-liter-capacity white plastic containers $(28.5 \mathrm{~cm}$ in diameter by $30.5 \mathrm{~cm}$ deep). Each container was buried in a field at The University of Arizona Yuma Mesa Agricultural Center so that the upper lip of each container was level with the surface of the field soil. Each container was considered a replicate microplot. Soil for the control treatment was maintained in microplots without irrigation. The flooding treatment was achieved by completely saturating the soil with water and maintaining a 2-cm layer of water on the soil surface by daily addition of water to replace that lost due to evaporation (19). The solarization treatment was accomplished by thoroughly saturating soil with water, then covering the soil with 1.0mil-thick solid clear polyethylene plastic containing a 180-day UV stabilizer (Water Tech, Charlotte, NC). The microplot containers used for the soil solarization treatment contained holes in the bottom to allow drainage of excess water, whereas no drain holes were present in microplot containers used for the soil flooding treatment. At the end of treatment intervals of 2, 4, 6, and 8 weeks, no additional water was added to flooded microplots and plastic was removed from solarized microplots. Soil remained in microplots without further irrigation until samples were collected to initiate bioassay trials. The time interval from cessation of soil treatments to initiation of bioassay trials ranged from 2 to 3.5 and 3.5 to 5 months for the soil treatment trials in 2003 and 2004, respectively. Five replicate microplots were established as controls and for each treatment intervalsoil treatment combination. Temperature in one control, flooded, and solarized microplot was recorded hourly at a soil depth of 10 and $23 \mathrm{~cm}$ for the duration of each trial from 23 July to 24 September 2003 and 13 July to 10 September 2004.

Crisphead lettuce (cv. Lighthouse) was seeded in transplant trays containing cells $2.5 \mathrm{~cm}$ square at the top and $5.0 \mathrm{~cm}$ deep filled with potting mix (Aqua Guard, St. Louis). Trays containing lettuce seed were maintained in the greenhouse until seedling emergence, then moved outdoors for further seedling growth. White plastic pots with a capacity of $473 \mathrm{~cm}^{3}(9.0 \mathrm{~cm}$ in diameter by $13.5 \mathrm{~cm}$ deep) were filled with soil from microplots: two pots with soil from a depth of 2 to $8 \mathrm{~cm}$ and two pots with soil from a depth of 20 to $26 \mathrm{~cm}$ from each microplot. When lettuce seedlings had developed four true leaves, a plant was transplanted into each pot containing soil on 25 November 2003 and 22 December 2004, then maintained in the greenhouse. Plants were watered daily and fertilized weekly with Miracle Gro fertilizer (Scotts Co., Marysville, OH). Hourly temperature of the soil within a pot was recorded at a depth of $10 \mathrm{~cm}$. The 2003 and 2004 bioassay trials were concluded after 2 months, at which time plant fresh weight as well as foliar and root symptom disease ratings were determined. Plant weight values recorded in 2003 are for the entire plant, whereas values in 2004 are for the aboveground portion of plants. Foliar disease symptoms were rated according to a scale where $1=$ no apparent disease, 2 = slight to moderate stunting, $3=$ severe stunting and yellowing, and $4=$ dead plant, whereas root disease symptoms in the tap root cortex were rated as $1=$ no discoloration, 2 = slight to moderate yellowing, $3=$ slight to moderate red streaking, and $4=$ necrotic tissue present. Although the bioassay trials were conducted in the winter, the temperatures in the greenhouse were conducive for development of Fusarium wilt.

Field solarization trials. Field trials were conducted from 2004 to 2007 to evaluate the efficacy of soil solarization as a potential management tool for Fusarium wilt of lettuce (Table 1). Raised beds, either listed but unshaped or shaped and ready for planting, were solarized for 1 or 2 months during the summer in a 2-ha commercial field in southwestern Arizona. The listed but unshaped beds were $107 \mathrm{~cm}$ wide at the base and tapered to a rounded ridge at their apex, whereas shaped beds were $107 \mathrm{~cm}$ wide at their base with a flat top surface $51 \mathrm{~cm}$ wide. Soil aggregates in unshaped beds were larger and less densely packed compared with those in shaped beds. The distance between both unshaped and shaped bed centers was 107 $\mathrm{cm}$. This was the same field from which soil was collected for the microplot studies described earlier. Crisphead lettuce was planted in this field in September 2003 and was severely affected by Fusarium wilt when the crop was terminated in November. Wheat was grown after lettuce and, following harvest in June 2004, the residue was incorporated into the soil and primary beds were listed but not shaped. Twelve days after a furrow irrigation, five 15.2-m lengths of bed were covered on 3 August with the 1.0-ml-thick clear plastic described earlier and solarized until 13 September. Five beds of the same length, alternated with solarized beds in the field, were not covered with clear plastic and served as a control. Soil temperature was recorded at a depth of 5 and $23 \mathrm{~cm}$ in a bed covered with plastic as well as in an uncovered bed. One additional furrow irrigation of all beds was performed on 1 September. At the conclusion of the solarization treatment on 13 September, all beds were shaped and planted to crisphead let-

Table 1. Experimental parameters for field solarization trials and subsequent assessment of Fusarium wilt on lettuce plantings

\begin{tabular}{llccccc}
\hline Year & Bed type & $\begin{array}{c}\text { Days from final irrigation } \\
\text { to laying of 1.0-mil plastic }\end{array}$ & $\begin{array}{c}\text { Solarization dates and duration } \\
\text { (days) }\end{array}$ & $\begin{array}{c}\text { Crisphead lettuce } \\
\text { cultivar }\end{array}$ & Seeding date & Trial end date \\
\hline 2004 & Unshaped & 12 & 3 August-13 September (41) & Lighthouse & 10 October \\
2005 & Shaped & 12 & 7 July-4 August (28) & Lighthouse & 13 September & 14 January \\
& $\ldots$ & 12 & 7 July-1 September (56) & Lighthouse & 13 September & 18 November \\
2006 & Unshaped & 12 & 3 July-2 August (30) & EXP-9145 & 16 September & 17 November \\
& $\ldots$ & 12 & 3 July-10 September (69) & EXP-9145 & 16 September & 17 November \\
& Shaped & 15 & 6 July-2 August (27) & EXP-9145 & 16 September & 17 November \\
& $\ldots$ & 15 & 6 July-10 September (66) & EXP-9145 & 16 September & 17 November \\
2007 & Shaped & 4 & 14 August-16 September (33) & Raider & 19 September & 13 December \\
\hline
\end{tabular}


tuce (cv. Lighthouse) on 10 October 2004. The bed-shaping procedure removed the upper portion from each unshaped bed and redistributed the soil, primarily to the sides of the resultant shaped bed. Plots were planted and managed using standard commercial practices, using raised beds with $107 \mathrm{~cm}$ between bed centers, with each bed containing two rows of lettuce spaced approximately $30 \mathrm{~cm}$ apart. Each plot in this trial contained 100 plants. The incidence of Fusarium wilt was recorded on 9 December and again at plant maturity on 14 January 2005. Each plant within a plot was counted as diseased if the plant was dead or stunted and displayed the usual symptoms of wilting and yellowing associated with Fusarium wilt of lettuce. All living plants with these symptoms were not marketable at plant maturity. At the end of the trial, the taproots of some symptomatic plants were harvested and necrotic cortex tissue was placed on potato dextrose agar to verify the presence of $F$. oxysporum f. sp. lactucae.

Additional solarization trials were conducted from 2005 to 2007 , each in an area of the 2-ha commercial field not part of a previous solarization trial. In 2005, beds were prepared and shaped 12 days after a flood irrigation of an area of the field that previously contained crisphead lettuce infected with Fusarium wilt followed by a planting of wheat. Five beds, $51 \mathrm{~cm}$ wide at the top and $30.5 \mathrm{~m}$ in length, either were covered with clear plastic and solarized from 7 July to 4 August or 1 September or not covered with plastic to serve as the control (Table 1). Following the end of the longest solarization period, beds were planted to crisphead lettuce (cv. Lighthouse) on 13 September. Each of the five replicate plots per treatment in this trial contained 220 plants. The incidence of Fusarium wilt was recorded on 12 and 24 October and, finally, on 18 November 2005. For 2006, following a crop of crisphead lettuce infected with Fusarium wilt, the field was flood irrigated; then, unshaped and shaped beds $30.5 \mathrm{~m}$ long were prepared 12 and 15 days later, respectively. Unshaped beds were solarized from 3 July to 2 August or 10 September, shaped beds from 6 July to 2 August or 10 September, and both unshaped and shaped beds not covered with plastic served as controls. At the end of the longest solarization period, unshaped beds were shaped and all beds planted to crisphead lettuce (cv. EXP-9145) on 16 September. Each of the four replicate plots per treatment in this trial contained 230 plants. The incidence of Fusarium wilt was recorded 11 and 30 October and at plant maturity on 17 November 2006. For the final trial conducted in 2007, beds were prepared and shaped 12 days after a flood irrigation of the field following a crop of crisphead lettuce infected with Fusarium wilt. Additional moisture was added by sprinkler irrigation after beds were shaped, followed 4 days later by covering four beds $(30.5 \mathrm{~m}$ in length) with clear plastic and solarizing these beds from 14 August to 16 September or not covering an equal number of beds to serve as the control (Table 1). Following solarization, beds were planted to crisphead lettuce (cv. Raider) on 19 September. Each of the four replicate plots per treatment in this trial contained 230 plants. The incidence of Fusarium wilt was recorded on 5 November and at plant maturity on 13 December 2007.

Soil temperature during each solarization trial was recorded hourly at depths of 5 and $23 \mathrm{~cm}$. Soil moisture content in solarized and nonsolarized beds was determined gravimetrically during the course of field solarization trials in 2006 and 2007. Soil moisture values presented are the means from three and two soil samples per treatment for soil depth and bed shape in 2006 and 2007, respectively.

Analysis of data. The SigmaPlot 11 software package (Systat Software, Inc, San Jose, CA) was used for statistical analysis of data. Data determined to be from normally distributed populations with the same variances were analyzed by the parametric unpaired $t$ test (for comparing two means) or one-way analysis of variance test (for more than two means). Means were compared and separated at $P$ $=0.05$ according to the Holm-Sidak test. When data failed tests for normality or equal variance, the nonparametric MannWhitney rank sum test (for two values) or the Kruskal-Wallis one-way analysis of variance on ranks test (for more than two values) were used to analyze data. These values were compared and separated at $P<$ 0.05 by the Tukey Test.

\section{RESULTS}

Microplot and bioassay trials. At the conclusion of both the 2003 and 2004 bioassay trials, fresh weight of lettuce plants grown in soil containing $F$. oxysporum $\mathrm{f}$. sp. lactucae that was subjected to solarization for a period of 2, 4, 6, and 8 weeks was significantly higher than that recorded for plants grown in nontreated soil (Table 2). This significant difference was noted for soil collected from a depth of 2 to $8 \mathrm{~cm}$ as well as from a depth of 20 to $26 \mathrm{~cm}$ within microplots. Growth of lettuce plants in soil subjected to flooding occasionally was significantly higher compared with plants grown in nontreated soil; however, the effect was not consistent over time, year, and depth from which soil was collected within microplots (Table 2). Fresh weight of lettuce plants grown in soil collected from untreated soil microplots at a depth of 2 to $8 \mathrm{~cm}$ was significantly greater than growth of plants in soil from a depth of 20 to $26 \mathrm{~cm}$ in the same microplots in 2003 but not in 2004 (Table 2).

Compared with plants grown in nontreated soil, the Fusarium wilt foliar symp- tom rating of lettuce plants at the conclusion of the bioassay phase of the 2003 trial was significantly lower for plants grown in soil from a depth of 2 to $8 \mathrm{~cm}$ in microplots solarized for 4,6 , and 8 weeks and in soil collected from a depth of 20 to $26 \mathrm{~cm}$ within microplots solarized for 2,4 , 6 , and 8 weeks (Table 2). The lettuce taproot cortex disease rating was significantly lower in plants grown in soil collected from a depth of 2 to $8 \mathrm{~cm}$ in microplots solarized for 6 and 8 weeks and in soil collected from a depth of 20 to $26 \mathrm{~cm}$ within microplots solarized from 2 to 8 weeks. In microplots flooded from 2 to 8 weeks, the Fusarium wilt foliar and root ratings were reduced significantly for plants grown in soil collected at a depth of 20 to $26 \mathrm{~cm}$; however, there was no effect of flooding on the same disease ratings for soil collected at a depth of 2 to $8 \mathrm{~cm}$ from microplots flooded for any tested interval of time (Table 2). In the 2004 trial, there were no significant differences in Fusarium wilt foliar or root ratings among soil treatments within untreated, flooded, and solarized microplots for any time interval at either soil depth sampled. The mean temperature of soil at a depth of $10 \mathrm{~cm}$ within pots during the bioassay trials was 18 and $20^{\circ} \mathrm{C}$ in 2003 and 2004 , respectively.

For both the 2003 and 2004 soil treatment experiments, the mean temperature of soil in microplots at a depth of $5 \mathrm{~cm}$ during both the 1- and 2-month treatment periods for nonsolarized, solarized, and flooded soil was 39,45 , and $32^{\circ} \mathrm{C}$, respectively. At a soil depth of $23 \mathrm{~cm}$, the mean temperature for the same respective soil treatments was 36,40 , and $34^{\circ} \mathrm{C}$. Considering both trials together, the mean number of hours during the 2-month treatment period that soil at a depth of $5 \mathrm{~cm}$ was at or above 40,45 , and $50^{\circ} \mathrm{C}$ in nonsolarized soil was 512,256 , and 84 h, respectively, compared with values in solarized soil of 563,414 , and $262 \mathrm{~h}$ and in flooded soil of 10,0 , and $0 \mathrm{~h}$, respectively. The number of hours that mean temperatures at a soil depth of $23 \mathrm{~cm}$ were at or above 40, 45, and $50^{\circ} \mathrm{C}$ was 127,4 , and $0 \mathrm{~h}$ for nonsolarized; 380, 84, and $0 \mathrm{~h}$ for solarized; and 0 , 0 , and $0 \mathrm{~h}$ for flooded soil.

Field solarization trials. In the initial trial conducted in 2004, unshaped beds were subjected to solarization under plastic for 41 days. In a subsequent planting of crisphead lettuce (cv. Lighthouse), the incidence of diseased plants due to $F$. $o x$ ysporum f. sp. lactucae in these solarized plots was 6 and $29 \%$ on 9 December and at crop maturity on 14 January, respectively, whereas, in nonsolarized plots, significantly higher values of 16 and $50 \%$ diseased plants were recorded for the same respective dates (Table 3 ).

In the 2005 study, where shaped beds were solarized for 28 or 56 days, the incidence of diseased crisphead lettuce plants 
(cv. Lighthouse) due to the Fusarium pathogen in solarized plots was 0 and $1 \%$ on 12 and 24 October, respectively, whereas significantly higher values of 11 and $71 \%$ diseased plants were recorded in nonsolarized plots on the same respective dates. The final disease incidence at crop maturity on 18 November in nonsolarized plots was $92 \%$, whereas disease values in plots solarized for 28 and 56 days were significantly lower, at 9 and $8 \%$, respectively (Table 3 ). There was no significant difference in disease incidence among plots solarized for 28 or 56 days at any of the disease evaluation dates.

The incidence of Fusarium wilt in 2006 for crisphead lettuce (cv. EXP-9145) grown on unshaped beds solarized for 30 days was 7 and $37 \%$ on 11 and 30 October, respectively, and, after solarization for 69 days, was 3 and $32 \%$ for the same respective dates. In comparison, disease frequency on unshaped nonsolarized beds on 11 and 30 October was 15 and $79 \%$, respectively. For each evaluation date, the only significant difference in the extent of Fusarium wilt was that recorded on 30 October between unshaped beds solarized for 30 days and nonsolarized beds. At crop maturity on 17 November, there was no significant difference in Fusarium wilt incidence between unsolarized plots and those solarized for 30 or 69 days (Table 3).

In 2006, the incidence of Fusarium wilt for lettuce grown on shaped beds solarized for 27 days was 3 and $22 \%$ on 11 and 30
October, respectively, and, after solarization for 66 days, was 3 and $20 \%$ for the same respective dates. On the other hand, disease frequency on shaped nonsolarized beds on 11 and 30 October was 15 and $56 \%$, respectively. The difference in the extent of Fusarium wilt on nonsolarized beds compared with those solarized for 27 days was significant on 30 October, whereas the difference in disease incidence on nonsolarized beds compared with beds solarized for 66 days was significant on both evaluation dates. At crop maturity on 17 November, disease levels were significantly lower on shaped beds solarized for 27 and 66 days compared with nonsolarized beds (Table 3 ).

In the trial conducted in 2007, shaped beds were subjected to solarization under plastic for 33 days. Disease incidence due to $F$. oxysporum f. sp. lactucae in solarized plots containing crisphead lettuce (cv.

Table 3. Effect of soil solarization on subsequent development of Fusarium wilt on lettuce in 2004 to 2007 field trials

\begin{tabular}{lccc}
\hline Year, solarization period (days) & Soil temperature $\left({ }^{\circ} \mathbf{C}\right)^{\mathbf{y}}$ & Beds shaped & Disease incidence $(\%)^{\mathbf{z}}$ \\
\hline 2004 & 37 & No & $50 \mathrm{a}$ \\
0 & 41 & No & $29 \mathrm{~b}$ \\
41 & & & $92 \mathrm{a}$ \\
2005 & 41 & Yes & $9 \mathrm{~b}$ \\
0 & 47 & Yes & $8 \mathrm{~b}$ \\
28 & 46 & Yes & $100 \mathrm{a}$ \\
56 & & & $100 \mathrm{a}$ \\
2006 & 38 & No & $84 \mathrm{ab}$ \\
0 & 38 & Yes & $52 \mathrm{~b}$ \\
0 & 45 & No & $79 \mathrm{ab}$ \\
30 & 49 & Yes & $44 \mathrm{~b}$ \\
27 & 44 & No & $67 \mathrm{a}$ \\
69 & 48 & Yes & $25 \mathrm{~b}$ \\
2007 & 41 & Yes & \\
0 & 44 & Yes & \\
33 & & & \\
\hline
\end{tabular}

${ }^{y}$ Mean soil temperature at a depth of $5 \mathrm{~cm}$ during solarization period.

${ }^{\mathrm{z}}$ Percentage of plants that were dead or diseased and displayed typical symptoms of Fusarium wilt at crop maturity. Values for each year followed by a different letter are significantly different according to the $t$ test $(P=0.13$ in 2004 and $P<0.001$ in 2007) or the Tukey Test $(P<0.05$ in 2005 and 2006).

Table 2. Effect of flooding or solarization of soil in microplots on subsequent development of Fusarium wilt on lettuce plants in 2003 and 2004

\begin{tabular}{|c|c|c|c|c|c|c|c|c|c|}
\hline \multirow[b]{3}{*}{ Rating $^{\mathrm{z}}$} & \multirow[b]{3}{*}{ Soil treatment } & \multicolumn{8}{|c|}{ Disease severity and plant growth ${ }^{y}$} \\
\hline & & \multicolumn{4}{|c|}{ Depth of 2 to $8 \mathrm{~cm}$} & \multicolumn{4}{|c|}{ Depth of 20 to $26 \mathrm{~cm}$} \\
\hline & & 2 weeks & 4 weeks & 6 weeks & 8 weeks & 2 weeks & 4 weeks & 6 weeks & 8 weeks \\
\hline \multicolumn{10}{|l|}{2003} \\
\hline \multirow[t]{3}{*}{ Weight } & Control & $29.9 \mathrm{~b}$ & $29.9 \mathrm{~b}$ & $29.9 \mathrm{~b}$ & $29.9 \mathrm{~b}$ & $8.8 \mathrm{~b}$ & $8.8 \mathrm{~b}$ & $8.8 \mathrm{~b}$ & $8.8 \mathrm{~b}$ \\
\hline & Flood & $47.8 \mathrm{a}$ & $45.4 \mathrm{a}$ & $42.3 \mathrm{~b}$ & $43.9 \mathrm{~b}$ & $47.5 \mathrm{a}$ & $47.8 \mathrm{a}$ & $45.7 \mathrm{a}$ & $43.7 \mathrm{a}$ \\
\hline & Solarize & $51.0 \mathrm{a}$ & $50.7 \mathrm{a}$ & $51.8 \mathrm{a}$ & $48.9 \mathrm{a}$ & $47.9 \mathrm{a}$ & $48.2 \mathrm{a}$ & $48.3 \mathrm{a}$ & $51.9 \mathrm{a}$ \\
\hline \multirow[t]{3}{*}{ Foliar } & Control & $2.4 \mathrm{a}$ & $2.4 \mathrm{a}$ & $2.4 \mathrm{a}$ & $2.4 \mathrm{a}$ & $3.7 \mathrm{a}$ & $3.7 \mathrm{a}$ & $3.7 \mathrm{a}$ & $3.7 \mathrm{a}$ \\
\hline & Flood & $2.6 \mathrm{a}$ & $2.0 \mathrm{a}$ & $1.8 \mathrm{a}$ & $1.9 \mathrm{ab}$ & $2.2 \mathrm{~b}$ & $2.0 \mathrm{~b}$ & $1.4 \mathrm{~b}$ & $1.7 \mathrm{~b}$ \\
\hline & Solarize & $2.0 \mathrm{a}$ & $1.3 \mathrm{~b}$ & $1.1 \mathrm{~b}$ & $1.3 \mathrm{~b}$ & $2.0 \mathrm{~b}$ & $1.5 \mathrm{~b}$ & $1.2 \mathrm{~b}$ & $1.1 \mathrm{~b}$ \\
\hline \multirow[t]{3}{*}{ Root } & Control & $2.9 \mathrm{a}$ & $2.9 \mathrm{a}$ & $2.9 \mathrm{a}$ & $2.9 \mathrm{a}$ & $3.9 \mathrm{a}$ & $3.9 \mathrm{a}$ & $3.9 \mathrm{a}$ & $3.9 \mathrm{a}$ \\
\hline & Flood & $2.8 \mathrm{a}$ & $2.4 \mathrm{a}$ & $2.4 \mathrm{a}$ & $2.6 \mathrm{a}$ & $2.4 \mathrm{~b}$ & $2.3 \mathrm{~b}$ & $2.4 \mathrm{~b}$ & $2.5 \mathrm{~b}$ \\
\hline & Solarize & $2.0 \mathrm{a}$ & $2.0 \mathrm{a}$ & $2.0 \mathrm{~b}$ & $2.0 \mathrm{~b}$ & $2.0 \mathrm{~b}$ & $2.0 \mathrm{~b}$ & $2.0 \mathrm{~b}$ & $2.0 \mathrm{~b}$ \\
\hline \multicolumn{10}{|l|}{2004} \\
\hline \multirow[t]{3}{*}{ Weight } & Control & $80 \mathrm{~b}$ & $80 \mathrm{~b}$ & $80 \mathrm{c}$ & $80 \mathrm{c}$ & $90 \mathrm{~b}$ & $90 \mathrm{~b}$ & $90 \mathrm{~b}$ & $90 \mathrm{~b}$ \\
\hline & Flood & $121 \mathrm{ab}$ & $105 \mathrm{ab}$ & $112 \mathrm{~b}$ & $114 \mathrm{~b}$ & $126 \mathrm{~b}$ & $107 \mathrm{~b}$ & $103 \mathrm{~b}$ & $128 \mathrm{ab}$ \\
\hline & Solarize & $143 \mathrm{a}$ & $134 \mathrm{a}$ & $141 \mathrm{a}$ & $156 \mathrm{a}$ & $164 \mathrm{a}$ & $164 \mathrm{a}$ & $145 \mathrm{a}$ & $154 \mathrm{a}$ \\
\hline \multirow[t]{3}{*}{ Foliar } & Control & $1.9 \mathrm{a}$ & $1.9 \mathrm{a}$ & $1.9 \mathrm{a}$ & $1.9 \mathrm{a}$ & $2.1 \mathrm{a}$ & $2.1 \mathrm{a}$ & $2.1 \mathrm{a}$ & $2.1 \mathrm{a}$ \\
\hline & Flood & $1.3 \mathrm{a}$ & $1.1 \mathrm{a}$ & $1.0 \mathrm{a}$ & $1.0 \mathrm{a}$ & $1.1 \mathrm{a}$ & $1.0 \mathrm{a}$ & $1.0 \mathrm{a}$ & $1.0 \mathrm{a}$ \\
\hline & Solarize & $1.0 \mathrm{a}$ & $1.1 \mathrm{a}$ & $1.0 \mathrm{a}$ & $1.0 \mathrm{a}$ & $1.0 \mathrm{a}$ & $1.0 \mathrm{a}$ & $1.0 \mathrm{a}$ & $1.0 \mathrm{a}$ \\
\hline \multirow[t]{3}{*}{ Root } & Control & $1.8 \mathrm{a}$ & $1.8 \mathrm{a}$ & $1.8 \mathrm{a}$ & $1.8 \mathrm{a}$ & $1.9 \mathrm{a}$ & $1.9 \mathrm{a}$ & $1.9 \mathrm{a}$ & $1.9 \mathrm{a}$ \\
\hline & Flood & $1.3 \mathrm{a}$ & $1.2 \mathrm{a}$ & $1.0 \mathrm{a}$ & $1.1 \mathrm{a}$ & $1.3 \mathrm{a}$ & $1.4 \mathrm{a}$ & $1.0 \mathrm{a}$ & $1.0 \mathrm{a}$ \\
\hline & Solarize & $1.0 \mathrm{a}$ & $1.2 \mathrm{a}$ & $1.0 \mathrm{a}$ & $1.0 \mathrm{a}$ & $1.0 \mathrm{a}$ & $1.0 \mathrm{a}$ & $1.0 \mathrm{a}$ & $1.0 \mathrm{a}$ \\
\hline
\end{tabular}

y Soil from depths indicated in microplots after treatment for each time period. From each replicate microplot, two samples of soil were collected at a depth of 2 to 8 and 20 to $26 \mathrm{~cm}$ and placed in $473-\mathrm{cm}^{3}$ capacity white plastic pots. Lettuce seedlings (cv. Lighthouse) were planted into the soil in each pot on 25 November 2003 and 22 December 2004 and maintained in a greenhouse until termination of trials 2 months later, at which time disease ratings and fresh weight of plants was determined. Each value was derived from 10 lettuce plants grown in soil from each of the treatment interval-soil treatment combinations or from control microplots. Values in each column for each year and type of disease rating parameter followed by a different letter are significantly different according to the Tukey Test $(P<0.05)$.

${ }^{z}$ Disease rating. Plant weight in grams; values for 2003 are the weight of the entire plant (above- and belowground parts) whereas 2004 values are the weight of the aboveground parts of plants only. Foliar symptom rating scale: $1=$ no apparent disease; $2=$ slight to moderate stunting; $3=$ severe stunting and yellowing; 4 = dead plant. Tap root cortex rating scale: $1=$ no discoloration; $2=$ slight to moderate yellowing; $3=$ slight to moderate red streaking; $4=$ necrotic tissue present. 
Raider) was 6 and $25 \%$ on 5 November and at crop maturity on 13 December, respectively, whereas, in nonsolarized plots, significantly higher values of 19 and $67 \%$ were recorded for the same respective dates (Table 3).

Compared with nonsolarized plots, the mean temperature for solarized soil at a depth of $5 \mathrm{~cm}$ was higher by $4^{\circ} \mathrm{C}$ in unshaped beds in $2004 ; 5$ to $6^{\circ} \mathrm{C}$ in shaped beds in 2005; 6 to 7 and 10 to $11^{\circ} \mathrm{C}$ in unshaped and shaped beds, respectively, in 2006; and $3^{\circ} \mathrm{C}$ in shaped beds in 2007 (Table 3). Considering all four field solarization trials together, including unshaped and shaped beds, at a soil depth of $5 \mathrm{~cm}$ the mean number of hours during the single or longest solarization periods for that year that were at or above 40,45 , and $50^{\circ} \mathrm{C}$ in nonsolarized soil was 330,103 , and $3 \mathrm{~h}$, respectively, compared with values in solarized soil of 635, 375, and 211 $\mathrm{h}$, respectively. On the other hand, at a soil depth of $23 \mathrm{~cm}$, mean temperature values were at or above 40,45 , and $50^{\circ} \mathrm{C}$ in nonsolarized soil for 66,0 , and $0 \mathrm{~h}$, respectively, compared with periods in solarized soil of 100,1 , and $0 \mathrm{~h}$, respectively.

In the 2006 field trial, on 6 July at the start of solarization for shaped beds and 3 days after beginning solarization for unshaped beds, the percent soil water content in solarized shaped and unshaped beds at a depth of $5 \mathrm{~cm}$ was 11.4 and $13.7 \%$, respectively, compared with 8.8 and $13.0 \%$ for respective nonsolarized plots. At a depth of $23 \mathrm{~cm}$ on the same date, the mean percent water content for shaped and unshaped solarized beds was 16.3 and $17.7 \%$, respectively, and 16.4 and $19.5 \%$ for respective nonsolarized plots. By 22 July, the percent soil water content in solarized shaped and unshaped beds at a depth of 5 cm was 12.0 and $5.5 \%$, respectively, compared with 3.8 and $3.0 \%$ for respective nonsolarized plots. At a depth of $23 \mathrm{~cm}$ on the same date, the mean percent water content for shaped and unshaped solarized beds was 15.5 and $15.9 \%$, respectively, and 14.7 and $15.7 \%$ for respective nonsolarized plots. In 2007, the mean soil water content at the end of the solarization period on 16 September at a depth of 5 and $23 \mathrm{~cm}$ in solarized shaped beds was 15.6 and $16.2 \%$, respectively, compared with respective values of 5.7 and $10.8 \%$ in nonsolarized beds.

\section{DISCUSSION}

In microplot studies, lettuce plant growth in soil containing $F$. oxysporum $\mathrm{f}$. sp. lactucae that was solarized from 2 to 8 weeks was consistently greater than growth in nontreated soil. This effect was noted for soil collected from depths of 2 to 8 as well as 20 to $26 \mathrm{~cm}$. This growth response may be due to more than the direct effect of solarization on reduction of pathogen populations in soil, because solarization also is known to induce a plant growth response in soil free of known pathogens (2). Possible mechanisms for this growth response not related to pathogen control include increased nutrient availability in soil, elimination of minor pathogens or parasites, stimulation of beneficial microorganisms, destruction of phytotoxic substances in soil, and release of growth regulator-like substances (10).

Growth of lettuce in summer-flooded soil occasionally was significantly higher than in nontreated soil; however, the effect was not as consistent as that recorded for solarized soil in relation to treatment duration, trial year, and depth from which soil was collected. Also, significant reduction of foliar and taproot cortex disease ratings was more evident for lettuce plants grown in solarized compared with flooded soil. Due to the less-consistent effect of summer soil flooding compared with solarization on lettuce growth and development of Fusarium wilt, field evaluation of summer flooding was not addressed in these investigations. However, this potential disease management tool merits further examination. Soil flooding results in an accumulation of ammonia (31), which has been shown to reduce the population density of Fusarium spp. in soil (33). Flooding of soil also creates anaerobic conditions (31) that alter soil microbial communities (30) and may play a role in reducing the survival of some soilborne pathogens. In Australia, a summer flooding treatment for 60 days in fields infested with $F$. oxysporum f. sp. vasinfectum significantly reduced the occurrence of Fusarium wilt on subsequent cotton plantings (1). However, as noted by the researchers, one potential limitation of this procedure may be the availability of water for extended field flooding in arid locations.

In the four field trials conducted, the incidence of Fusarium wilt on lettuce sown in soil after solarization was reduced from 42 to $91 \%$ compared with disease in nonsolarized plots. In the single field trial that contained both unshaped and shaped beds, the reduction in Fusarium wilt for lettuce grown on solarized compared with nonsolarized beds was significantly different on shaped but not unshaped beds. One possible explanation for the higher reduction of Fusarium wilt on shaped compared with unshaped beds is that, in the process of shaping beds after solarization, the upper layer of soil from the unshaped bed is removed and redistributed, primarily to the sides of the resultant shaped bed. This upper layer of soil, which was subjected to higher temperatures and, presumably, was where solarization was more effective, was removed during the subsequent bedshaping operation to expose soil that was less effectively solarized due to its original depth in the soil profile. Also, some nonsolarized soil adjacent to the edges of solarized beds could have been incorporated into the final shaped bed by the bedshaping implement.
The two trials that compared 1- and 2month solarization periods on shaped beds did not reveal a significant advantage for the longer solarization period. In 2005, Fusarium wilt reduction after a $28-$ and 56day solarization period was $91 \%$ for both time periods and, in 2006, solarization durations of 27 and 66 days reduced the subsequent incidence of disease by 48 and $56 \%$, respectively. In general, populations of soilborne pathogens are greatly reduced at temperatures in the range of 40 to $50^{\circ} \mathrm{C}$ (10). In these studies, the mean soil temperature at a depth of $5 \mathrm{~cm}$ for the 1-month solarization period in 2005 and 2006 was 47 and $49^{\circ} \mathrm{C}$, respectively. Solarization periods exceeding 1 month may be beneficial in areas where soil temperatures are below levels achieved in these trials.

The elevated temperatures achieved by the soil solarization process are one important factor affecting the reduction of pathogen populations; however, the retention of soil moisture by the plastic film during the solarization process is also an important consideration. Soil moisture content at a depth of $5 \mathrm{~cm}$, when measured during and at the conclusion of soil solarization trials in 2006 and 2007, was always higher in solarized compared with nonsolarized soil. Soil moisture content is a critical factor, because microorganisms are much more resistant to heat under dry conditions. Water affects the heat stability of proteins; thus, when water is present, less energy is necessary for unfolding of peptide chains in proteins, which results in decreased heat resistance (24). Consequently, heating dry soil does not effectively control most plant pathogens (12). In addition to increasing the thermal sensitivity of soilborne microorganisms, moisture increases heat transfer or conduction in soil (28). Mahrer (15) found that saturated soils were optimal. In our field trials, various methods were used to add water to soil beds, including furrow irrigation after bed preparation, bed preparation after flood irrigation of a flat field, and bed construction following flood irrigation followed by sprinkler irrigation. An alternative and effective method of supplying moisture to soil before or during the solarization process would be through drip irrigation.

Time of exposure to potentially lethal temperatures in solarized soil can affect the death rate within a pathogen population, resulting in various degrees of reduction in viability $(10,25)$. Additionally, sublethal temperatures, which eliminate only a fraction of the pathogen population, may affect the survival of the remaining, potentially weakened propagules. Freeman and Katan (4) demonstrated that the viability of conidia of $F$. oxysporum $\mathrm{f}$. sp. niveum that were heat treated or exposed to solarized soil declined faster than unheated conidia. Disease incidence in watermelon seedlings inoculated with heat-treated conidia of the pathogen was reduced from 35 to $82 \%$, 
with a similar trend noted with $F$. oxysporum f. sp. melonis in muskmelon seedlings. In studies with other pathogens, sublethal doses of heat caused damage to sclerotia of Sclerotium rolfsii, which were then colonized by bacteria and actinomycetes (13), or made other pathogens more susceptible to antagonism by Trichoderma spp. $(23,29)$.

Soil solarization has been shown to significantly reduce the number of plants affected by Fusarium wilt in a subsequent planting of a susceptible lettuce cultivar. The long-term effect of the solarization treatment on disease development in additional lettuce plantings was not addressed in our studies. However, depressed levels of Fusarium wilt and increased cotton yields were recorded for as long as 3 years following soil solarization of several fields heavily infested with $F$. oxysporum f. sp. vasinfectum (11). Furthermore, disease incidence was lower in the second year when a resistant cotton cultivar was planted the first year followed by a susceptible cultivar in the second year, compared with two successive plantings of the susceptible cultivar, thus extending the beneficial effect of solarization. Other factors may affect the longevity of a solarization treatment as well. Care should be exercised to minimize reintroduction of $F$. oxysporum f. sp. lactucae from contaminated soil within furrows during farming operations. The potential ability of the lettuce pathogen to grow and multiply on crops other than lettuce also is a concern. Hubbard and Gerik (9) found that $F$. oxysporum f. sp. lactucae could be recovered from tomato, muskmelon, watermelon, and cotton seedlings inoculated with the lettuce pathogen 4 weeks earlier. Furthermore, the mean weight of muskmelon and watermelon plants was reduced 51 and $39 \%$, respectively, compared with plants not inoculated with $F$. oxysporum f. sp. lactucae.

The degree and duration of effective control of Fusarium wilt on lettuce can be maximized if soil solarization is used within an integrated program in conjunction with existing disease management tools, such as planting available tolerant or resistant lettuce cultivars and growing lettuce when lower soil temperatures are not conducive to disease development. An additional benefit of soil solarization is effective control of many types of weeds and some other soilborne pathogens of concern to lettuce growers (28).
LITERATURE CITED

1. Allen, S. J., and Lonergan, P. A. 2000. Control strategies for Fusarium wilt of cotton in Australia. Pages 136-138 in: Proc. Beltwide Cotton Conf. National Cotton Council of America, Memphis, TN.

2. Altman, J. 1970. Increased and decreased plant growth responses resulting from soil fumigation. Pages 216-221 in: Root Diseases and Soilborne Pathogens. T. A. Tousson, R. V. Bega, and R. E. Nelson, eds. University of California Press, Berkeley.

3. Chellemi, D. O., Olson, S. M., Mitchell, D. J., Secker, I., and McSorley, R. 1997. Adaptation of soil solarization to the integrated management of soilborne pests of tomato under humid conditions. Phytopathology 87:250-258.

4. Freeman, S., and Katan, J. 1988. Weakening effect of propagules of Fusarium by sublethal heating. Phytopathology 78:1656-1661.

5. Garibaldi, A., Gilardi, G., and Gullino, M. L. 2002. First report of Fusarium oxysporum on lettuce in Europe. Plant Dis. 86:1052.

6. Garibaldi, A., Gilardi, G., and Gullino, M. L. 2004. Varietal resistance of lettuce to Fusarium oxysporum f. sp. lactucae. Crop Prot. 23:845851.

7. Garibaldi, A., Minuto, A., Clematis, F., and Gullino, M. L. 2009. Effectiveness of soil application of Brassica dried pellets in combination with a simulation of soil solarization against Fusarium wilt of lettuce and basil. Protezione delle Colture. Pages 14-17.

8. Huang, J. H., and Lo, C. T. 1998. Wilt of lettuce caused by Fusarium oxysporum in Taiwan. Plant Pathol. Bull. 7:150-153.

9. Hubbard, J. C., and Gerik, J. S. 1993. A new wilt disease of lettuce incited by Fusarium oxysporum f. sp. lactucum forma specialis nov. Plant Dis. 77:750-754.

10. Katan, J. 1981. Solar heating (solarization) of soil for control of soilborne pests. Annu. Rev. Phytopathol. 19:211-236.

11. Katan, J., Fishler, G., and Grinstein, A. 1983. Short- and long-term effects of soil solarization and crop sequence on Fusarium wilt and yield of cotton in Israel. Phytopathology 73:1215-1219.

12. Katan, J., Greenberger, A., Alon, H., and Grinstein, A. 1976. Solar heating by polyethylene mulching for the control of diseases caused by soil-borne pathogens. Phytopathology 66:683688.

13. Lifshitz, R., Tabachnik, M., Katan, J., and Chet, I. 1983. The effect of sublethal heating on sclerotia of Sclerotium rolfsii. Can. J. Microbiol. 29:1607-1610.

14. Lodha, S. 1995. Soil solarization, summer irrigation and amendments for the control Fusarium oxysporum f. sp. cumini and Macrophomina phaseolina in arid soils. Crop Prot. 14:215-219.

15. Mahrer, H., Naot, O., Rawitz, E., and Katan, J. 1984. Temperature and moisture regimes in soils mulched with transparent polyethylene. Soil Sci. Soc. Am. J. 48:362-367.

16. Martyn, R. D., and Hartz, T. K. 1986. Use of soil solarization to control Fusarium wilt of watermelon. Plant Dis. 70:762-766.

17. Matheron, M. E., and Koike, S. T. 2003. First report of Fusarium wilt of lettuce caused by
Fusarium oxysporum f. sp. lactucae in Arizona. Plant Dis. 87:1365.

18. Matheron, M. E., McCreight, J. D., Tickes, B. R., and Porchas, M. 2005. Effect of planting date, cultivar, and stage of plant development on incidence of Fusarium wilt of lettuce in desert production fields. Plant Dis. 89:565-570.

19. Matheron, M. E., and Porchas, M. 2005. Influence of soil temperature and moisture on eruptive germination and viability of sclerotia of Sclerotinia minor and S. sclerotiorum. Plant Dis. 89:50-54.

20. Matuo, T., and Motohashi, S. 1967. On Fusarium oxysporum $\mathrm{f}$. $\mathrm{sp}$. lactucae $\mathrm{n}$. causing root rot on lettuce. Trans. Mycol. Soc. Jpn. 32:1315.

21. Millani, M. J., Etebarian, H. R., and Alizadeh, A. 1999. Occurrence of Fusarium wilt of lettuce in Shahre-Ray, Varamin and Karaj areas. Iran. J. Plant. Pathol. 35:44-45.

22. Moore, W. D. 1949. Flooding as a means of destroying the sclerotia of Sclerotinia sclerotiorum. Phytopathology 39:920-927.

23. Munnecke, D. E., Wilbur, W., and Darley, E. F. 1976. Effect of heating or drying on Armillaria mellea or Trichoderma viride and the relation to survival of A. mellea in soil. Phytopathology 66:1363-1368.

24. Precht, H., Christophersen, J., Hensel, H., and Larcher, W. 1973. Temperature and Life. Springer, Berlin.

25. Pullman, G. S., DeVay, J. E., and Garber, R. H. 1981. Soil solarization and thermal death: logarithmic relationship between time and temperature for four soilborne plant pathogens. Phytopathology 71:959-964.

26. Shelton, D. R., Sadeghi, A. M., and McCarty, G. E. 2000. Effect of soil-water content on denitrification during cover crop decomposition. Soil Sci. 165:365-371

27. Smith, S. N., DeVay, J. E., Hsieh, W.-H., and Lee, H.-J. 2001. Soil-borne populations of Fusarium oxysporum f. sp. vasinfectum, a cotton wilt fungus in California fields. Mycologia 93:737-743.

28. Stapleton, J. J., and DeVay, J. E. 1986. Soil solarization: a non-chemical approach for management of plant pathogens and pests. Crop Prot. 5:190-198.

29. Sztejnberg, A., Freeman, S., Chet, I., and Katan, J. 1987. Control of Rosellinia necatrix in soil and in apple orchard by solarization and Trichoderma harzianum. Plant Dis. 71:365369.

30. Unger, I. M., Kennedy, A. S., and Muzika, R. M. 2009. Flooding effects on soil microbial communities. Appl. Soil Ecol. 42:1-8.

31. Unger, I. M., Muzika, R. M., and Motavalli, P. P. 2010. The effect of flooding and residue incorporation on soil chemistry, germination and seedling growth. Environ. Exp. Bot. 69:113120.

32. Ventura, J. A., and Costa, H. 2008. Fusarium wilt caused by Fusarium oxysporum on lettuce in Espirito Santo, Brazil. Plant Dis. 92:976.

33. Zakaria, M. A., Lockwood, J. L., and Filonow, A. B. 1980. Reduction in Fusarium population density in soil by volatile degradation products of oilseed meal amendments. Phytopathology 70:495-499. 